\title{
Can Emotionally Intelligent Volleyball Players Be More Prone to Sportspersonship?
}

\author{
Suleyman Can \\ Correspondence: Suleyman Can, Muğla Sıtkı Koçman Üniversitesi, Turkey
}

Received: March 11, 2016 Accepted: March 26, $2016 \quad$ Online Published: April 7, 2016

doi:10.11114/jets.v4i7.1447 URL: http://dx.doi.org/10.11114/jets.v4i7.1447

\begin{abstract}
Emotional intelligence concept has been examined by researchers in the field of education as well as field of sports. When emotional intelligence theory examined, it comes to mind that emotional intelligence can be related to moral behaviors in sport. In this regard, the question of "Can emotional intelligence predict sportspersonship orientation?" comes to mind. Consistent with this question, we examined the relationship between sportspersonship orientation and emotional intelligence level of students participating in university volleyball second division competitions. 79 female and male volleyball players participated in this study. The age mean of participants was found to be $20.29 \pm 1.87$. $46.8 \%$ of participants was female $(n=37), 53.2 \%$ was male $(n=42) . \% 79.7$ of participants have reported that they are satisfied with their department $(n=63)$. \% 8.9 have reported they are not satisfied with their department while \%11.4 have reported that they are partially satisfied with their department. \%46 of participant have reported that sporting activities are enough $(\mathrm{n}=37)$. \%21.5 of them have reported that sporting activities are not enough $(\mathrm{n}=17)$ while $\% 31.6$ have reported that they are partially enough $(n=25)$. Significant difference was found between genders in terms of emotional appraisal $(\mathrm{p}<0.01)$, emphatic sensitivity $(\mathrm{p}<0.01)$, positive utilization $(\mathrm{p}<0.05)$, respect for social conventions $(\mathrm{p}<0.05)$, respect for rules and officials $(p<0.05)$, respect for one's full commitment toward sport participation $(p<0.05)$. Female volleyball players have reported higher scores than males in terms of all variables. It has been found that emotional intelligence predicts sportspersonship orientation of students participating in university volleyball second division competitions.
\end{abstract}

Keywords: emotional intelligence, sportspersonship, volleyball, moral, sport

\section{Introduction}

Emotional intelligence concept has been examined by researchers in the field of education (Chan, 2004; McPail, 2004; Parker et al., 2004; Humphrey et al., 2007; Esturgo-Deu and Sala-Roca, 2010; MacCannet al., 2011; Yin et al., 2013) as well as sport field (Ajayi and Fatokun, 2008; Zizzi et al., 2003; Lane et al., 2010). Different definitions of emotional intelligence have been provided in literature. Mayer \& Salovey (1997) defined emotional intelligence as helping thoughts and understanding emotions and emotional information to increase emotional and intellectual development, perceiving and reaching emotions and regulating them to organize emotions reflectively. Bar-On (2005) has defined emotional intelligence as an ability to be aware of emotions and one's self; understand weak and powerful aspects and state emotions nondestructively.

Some research has been conducted to examine the relationship between emotional intelligence and moral development (Pizarro and Salovey, 2002). Some researchers used the term emotionally intelligent nearly equal to moral (Goleman, 1995; Saarni, 1999). Pizarro and Salovey (2002) suggested that empathy, one of the four dimensions of emotional intelligence, could be considered as truly moral emotion because people understanding others' emotions and the signals that they send in any kind of communication are very important in social relations.

Negative emotions such as anger can motivate us to behave inappropriately if these kinds of emotions are not regulated (Pizarro and Salovey, 2002). At this point, regulation of emotions in ourselves becomes an important part of moral behavior. According to Pizarro and Salovey (2002) emotional reactions should be guided in the right direction. In sport, regulating negative emotions allows athletes to act in the philosophy of sportspersonship. Athletes good at regulation emotions and empathy are more likely to behave appropriate.

Another concept that can influence the moral behaviors suggested by Pizarro and Salovey (2002) is regulating emotions in others that are important as well as regulation of emotions in ourselves. For example, motivational speaking of a 
coach, teacher, and leader can be considered as regulation of emotions in others. Weinberg and Gould (2003) state that participation in an exercise program is able to build character, improve one's moral reasoning and educate him to apply sportsmanship. Learning sports activities through sports, physical education and health contain ethical values of fair play.

It can be said that fair play is one of the most important concepts when it comes to talk about moral and ethical values in sport. First of all, fair play was a concept related to trade (Erdemli, 2008, p. 386), in sport field, fair play is defined by Ylldıran and Sezen (2006) as a concept defining social, cultural and moral norms of sport without remaining limited by awareness of rules. Fair play is awareness that opponent/friend who compete or play sports together is always attached (Weinberg and Gould, 2003).

As the research results in literature have showed that emotional intelligence and moral development has positive direct or indirect relations, it can be said that examining the relationship between sportspersonship orientation and emotional intelligence level of students participating in university volleyball second division competitions will contribute to literature in the field of team sport research.

\section{Method}

\subsection{Participants}

Table 1. Demographic properties of participants

\begin{tabular}{lll}
\hline Variable & Frequency & Percentage \\
\hline Gender & 37 & 46.8 \\
Female & 42 & 53.2 \\
\hline Male & 2 & \\
\hline Department/Faculty/School & 2 & 2.5 \\
Tourism & 6 & 2.5 \\
Engineering & 40 & 7.6 \\
Physical Education and Sport & 7 & 50.6 \\
Economics and administrative sciences & 5 & 8.9 \\
Science and literature & 4 & 6.3 \\
Law & 3 & 5.1 \\
Interior architecture & 1 & 3.8 \\
Nursing & 6 & 1.3 \\
Education & 2 & 7.6 \\
Technology & 1 & 2.5 \\
Foreign languages & & 1.3 \\
\hline University & 20 & 25.3 \\
\hline Akdeniz & 17 & 21.3 \\
İzmir & 11 & 13.9 \\
Burdur & 7 & 8.9 \\
Uşak & 12 & 15.2 \\
Aydin & 12 & 15.2 \\
Muğla & & \\
\hline Licensed athlete & 72 & 91.1 \\
\hline Yes & 7 & 8.9 \\
No & 79 & 100.0 \\
\hline Total & 76 & 0.9 \\
\hline
\end{tabular}

79 female and male volleyball players participated in this study. The age mean of participants was found to be 20.29 $\pm 1.87 .46 .8 \%$ of participants was female $(n=37), 53.2 \%$ was male $(n=42)$. Students studying in fine arts $(n=2)$, tourism $(n=2)$, engineering $(n=6)$, physical education and sport $(n=40)$, economics and administrative sciences $(n=7)$, science and literature $(n=5)$, law $(n=4)$, interior architecture $(n=3)$, nursing $(n=1)$, education $(n=6)$, technology $(n=2)$, foreign languages $(n=1)$ at universities of Akdeniz $(n=20)$, Ege $(n=17)$, Mehmet Akif Ersoy $(n=11)$, Uşak ( $n=7)$, Adnan Menderes $(n=12)$, Sitkı Koçman $(n=12) . \% 91.1$ of the participants have reported to be licensed athlete $(n=72)$.

\subsection{Data Collection}

Multidimensional Sportspersonship Orientation Scale (MSOS): Multidimensional Sportspersonship Orientation Scale (MSOS), developed by Vallerand et al. (1997) and adapted to Turkish by Balçckanli-Sezen (2010), was used to determine sportspersonship orientation of participants. In this study, Cronbach's alpha value has been found to be 0.92.

Emotional intelligence scale: Schutte, Malouff, Hall, Haggerty, Cooper, Golden and Dornheim (1998) developed original emotional intelligence scale form consisting 33 items. Chan $(2004,2006)$ adapted this scale in a short form consisting of 12 items. Chan $(2004,2006)$ used these items to investigate the relationship between burnout and 
emotional intelligence. Scale was five-likert type. Chan found high scale reliability in his studies (Cronbach's Alpha = 0.82- 0.86). Senel (2013) used the same scale to determine emotional intelligence levels of university students, examined the factors in confirmatory factor analysis (CFA), and found that the scale confirmed four sub-dimensions. Aslan and Özata (2008) used the same scale for a research on health service workers. The scale had four sub-dimensions: emotional appraisal, positive regulation, emphatic sensitivity, and positive utilization. In this study, Cronbach's alpha value has been found to be 0.93 .

\subsection{Statistical Analysis}

Collected data was analyzed in SPSS 22.0 by using independent t-test, person product correlation and regression analysis.

\section{Results}

$\% 79.7$ of participants have reported that they are satisfied with their department $(\mathrm{n}=63) . \% 8.9$ have reported they are not satisfied with their department while \%11.4 have reported that they are partially satisfied with their department. \%46 of participant have reported that sporting activities are enough $(\mathrm{n}=37) . \% 21.5$ of them have reported that sporting activities are not enough $(\mathrm{n}=17)$ while $\% 31.6$ have reported that they are partially enough $(\mathrm{n}=25)$.

Table 2. Differences between genders in terms of emotional intelligence and sportspersonship orientation

\begin{tabular}{|c|c|c|c|c|c|c|c|c|}
\hline \multirow[t]{2}{*}{ Variables } & \multicolumn{3}{|c|}{ Female } & \multicolumn{5}{|c|}{ Male } \\
\hline & $\mathrm{n}$ & $\mathrm{X}$ & S.D & $\mathrm{n}$ & $X$ & S.D & $\mathrm{t}$ & $\mathrm{p}$ \\
\hline Emotional Appraisal & 37 & 4.42 & .47 & 42 & 3.93 & .85 & 3.06 & $0.00^{* *}$ \\
\hline Positive Regulation & 37 & 4.45 & .52 & 42 & 4.12 & .89 & 1.97 & 0.05 \\
\hline Emphatic Sensitivity & 37 & 4.57 & .43 & 42 & 4.20 & .69 & 2.78 & $0.00^{* * *}$ \\
\hline Positive Utilization & 37 & 4.57 & .57 & 42 & 4.21 & .75 & 2.37 & $0.02^{*}$ \\
\hline Respect for social conventions & 37 & 4.57 & .58 & 42 & 4.24 & .81 & 2.08 & $0.04^{*}$ \\
\hline Respect for rules and officials & 37 & 4.35 & .59 & 42 & 3.95 & .73 & 2.62 & $0.01^{*}$ \\
\hline Respect for one's full commitment toward sport participation & 37 & 4.66 & .40 & 42 & 4.31 & .70 & 2.61 & $0.01^{*}$ \\
\hline Respect and concern for the opponent & 37 & 4.15 & .78 & 42 & 4.00 & .83 & .831 & 0.40 \\
\hline
\end{tabular}

${ }^{* * *} \mathrm{p}<0.01,{ }^{*} \mathrm{p}<0.05$

Differences between genders in terms of emotional intelligence and sportspersonship orientation were shown in Table 1. Significant difference was found between genders in terms of emotional appraisal $(\mathrm{p}<0.01)$, emphatic sensitivity $(\mathrm{p}<0.01)$, positive utilization $(\mathrm{p}<0.05)$, respect for social conventions $(\mathrm{p}<0.05)$, respect for rules and officials $(\mathrm{p}<0.05)$, respect for one's full commitment toward sport participation $(\mathrm{p}<0.05)$. Female volleyball players have reported higher scores than males in terms of all variables.

Table 3. Correlations between emotional intelligence and sportspersonship orientation

\begin{tabular}{|c|c|c|c|c|c|c|c|c|}
\hline & $4.40 \pm 0.72$ & $4.14 \pm 0.70$ & $4.48 \pm 0.60$ & $4.07 \pm 0.80$ & $4.16 \pm 0.74$ & $4.28 \pm 0.75$ & $4.37 \pm 0.61$ & $4.38 \pm 0.69$ \\
\hline 1 & 1 & & & & & & & \\
\hline 2 & $.563^{* *}$ & 1 & & & & & & \\
\hline 3 & $.733^{* *}$ & $.569^{* *}$ & 1 & & & & & \\
\hline 4 & $.483^{* * *}$ & $.527^{* *}$ & $.511^{* * *}$ & 1 & & & & \\
\hline 5 & $.606^{* *}$ & $.411^{* * *}$ & $.684^{* *}$ & $.398^{* * *}$ & 1 & & & \\
\hline 6 & $.629^{* *}$ & $.345^{* *}$ & $.666^{* *}$ & $.408^{* *}$ & $.825^{* *}$ & 1 & & \\
\hline 7 & $.553^{* *}$ & $.367^{* * *}$ & $.688^{* *}$ & $.480^{* * *}$ & $.696^{* *}$ & $.753^{\text {*** }}$ & 1 & \\
\hline 8 & $.670^{* *}$ & $.482^{* *}$ & $.680^{* *}$ & $.453^{* *}$ & $.804^{* *}$ & $.763^{* *}$ & $.683^{* *}$ & 1 \\
\hline
\end{tabular}

Table 2 displays the correlation analysis between sub-dimensions of emotional intelligence and sportspersonship orientation. Positive correlations have been found between respect for social conventions and emotional appraisal ( $\mathrm{r}=.60$, $\mathrm{p}<.01)$, positive regulation $(\mathrm{r}=.62, \mathrm{p}<.01)$, emphatic sensitivity $(\mathrm{r}=.55, \mathrm{p}<.01)$, and positive utilization $(\mathrm{r}=.67, \mathrm{p}<.01)$. Positive correlations have been found between respect for rules and officials and emotional appraisal $(\mathrm{r}=.41, \mathrm{p}<.01)$, positive regulation $(\mathrm{r}=.34, \mathrm{p}<.01)$, emphatic sensitivity $(\mathrm{r}=.36, \mathrm{p}<.01)$, and positive utilization $(\mathrm{r}=.48, \mathrm{p}<.01)$. Positive correlations have been found between respect for one's full commitment toward sport participation and emotional appraisal $(\mathrm{r}=.68, \mathrm{p}<.01)$, positive regulation $(\mathrm{r}=.66, \mathrm{p}<.01)$, emphatic sensitivity $(\mathrm{r}=.68, \mathrm{p}<.01)$, and positive utilization $(\mathrm{r}=.68, \mathrm{p}<.01)$. Positive correlations have been found between respect and concern for the opponent and emotional appraisal $(r=.39, p<.01)$, positive regulation $(r=.40, p<.01)$, emphatic sensitivity $(r=.48, p<.01)$, and positive utilization $(\mathrm{r}=.45, \mathrm{p}<.01)$. 
Table 4. Basic regression analysis applied for the prediction of sportspersonship orientation by emotional intelligence

\begin{tabular}{llllllll}
\hline & $\beta$ & $\mathrm{t}$ & $\mathrm{p}$ & $\mathrm{R}^{2}$ & Adjusted $^{2}$ & $\mathrm{~F}$ & $\mathrm{p}$ \\
\hline RegressionCoefficient & 1.484 & 4.629 & .000 & 0.502 & 0.495 & 77.471 & .000 \\
Emotional Intelligence & .708 & 8.802 & .000 & & & & \\
\hline
\end{tabular}

Predictor: (Constant), Emotional Intelligence

Dependent variable: Sportspersonship orientation

Emotional intelligence has predicted sportspersonship orientationat the level of 50\% approximately (Adjusted $\mathrm{R}^{2}$ $=0.495)$. The hypothesized model has been found to be significant $(\mathrm{F}=77.471, \mathrm{p}=0.000)$. Positive correlation has been found between sportspersonship orientation and emotional intelligence (0.708) and this result has been found to be statistically significant $(\mathrm{t}=8.802, \mathrm{p}=0.000)$.

\section{Discussion}

The aim of this study was to examine the relationship between sportspersonship orientation and emotional intelligence level of students participating in university volleyball second division competitions.

Female volleyball players have reported higher scores than males in terms of emotional appraisal, emphatic sensitivity, and positive utilization. While this result is not consistent with some research (Chan, 2004; Hopkins and Bilimoria, 2008; Rastegar and Memarpour, 2009; Gürol et al. 2010; Şenel, 2013; Şenel et al., 2014; Adilogullari et al., 2014; Adilogullari and Senel, 2014), it is consistent with the research of Harrod and Scheer (2005) and Çolakoğlu et al., 2014).

Female volleyball players have reported higher scores than males in terms of respect for social conventions, respect for rules and officials, respect for one's full commitment toward sport participation. These results are consistent with some research in literature (Duda et al., 1991; Tsai and Fung, 2005).

Weiss and Bredemeier (1990) interpreted the gender differences in terms of sportspersonship, as males are more likely to accept aggression in sport and tend to be more tolerant of un-sportsperson like behavior. Kavussanu and Roberts (2001) are of the view that basic differences in achievement orientation between males and females are partly responsible for their differential regard for sportspersonship. Tsai and Fung (2005) suggested that females are more prone to mirror behaviors such as congratulating opponents after a loss, shaking hands with opponent's coach, rectifying unjust situations for opponent, helping a fallen opponent from the floor, controlling self when mistakes were made, and readiness to admit their own mistakes. With these interpretations of genders differences in terms of sportspersonship and the results of this study, it can be said that women athletes give more importance to moral values in sports than males do.

As we found females to be higher than males in terms of emotional intelligence, this can provide us the information emotionally intelligent volleyball players are more prone to sportspersonship behaviors. The findings of positive correlations between sub-dimensions of emotional intelligence and sportspersonship orientation support this view. In literature, some researchers have found positive correlations between emotional intelligence and moral values such as ethical climate (Deshpande and Joseph, 2009; Aslan et al., 2012). Carmeli (2003) suggested that emotional intelligence is a competency that drives positive outcomes and behavior. In their study investigating the relationship between sportspersonship orientation and empathy Balçıkanlı-Sezen and Yıldıran (2012) have revealed that the subscales of fair play were positively correlated with those of sportspersonship orientation. Valdesolo and DeSteno (2007) used a cognitive load paradigm to demonstrate that controlled cognitive processes are involved in rationalizing one's own unfair behavior. When individuals have the power to attenuate or regulate the emotions and the psychological pressure in a game, they can demonstrate a constructive interaction with the teammates, opponents, referees and spectators and so present an attractive fair play (Abdoli et al. 2008). Although there are studies suggesting that emotional intelligence and moral values are correlational, in the study where 124 accounting and finance students participated (Pathak, et al., 2013), it was analyzed if emotional intelligence predicted ethical orientation and no significant effect have been found. In this study, it has been found that emotional intelligence predicts sportspersonship orientation of volleyball players.

The aim of this study was to examine relationship between emotional intelligence and sportspersonship orientation of students participating in university volleyball second division competitions. The findings of this study and research conducted in literature have showed that emotionally intelligent individuals are more prone to sportspersonship. In this study, we found that emotional intelligence was a predictor of sportspersonship. Namely, individuals having higher level of emotional intelligence are more likely to act appropriately in sporting field. It can be concluded that emotional intelligence can be a factor avoiding inappropriate behaviors such as cheating, violence and aggression in sport.

Some recommendations for future can be added. Educating coaches, athletes, students, and fans based on enhancing emotional intelligence level can be a key factor preventing violence and encouraging moral behaviors in sport. Isberg 
(2000) suggested that training such as assertiveness, communication skills and team building could be beneficial to prevent improper behaviors in sport. Besides, we can suggest that educational program based on emotional intelligence can be useful for this purpose in both sport clubs and schools.

Different athlete groups and branches can be included in future studies. Differences between contact and contactless branches can be examined in terms of emotional intelligence and sportspersonship.

\section{References}

Abdoli, B., Rezaie, Z. F., \& Sani, S. H. Z. (2008). The predictive effect of emotional intelligence and its components on anger and aggressiveness in soccer players. International Journal of Psychology, 2(2), 36 -51.

Adilogullari, I., \& Şenel, E. (2014). Examination of the relationship between general self-efficacy beliefs, emotional intelligence levels and emotional self-efficacy levels of students in school of physical education and sport. Anthropologist, 18(3), 893-902.

Adilogullari, I., Ulucan, H., \& Şenel, E. (2014). Analysis of the relationship between the emotional intelligence and professional burnout levels of teachers. Educational Research and Reviews, 9(1), 1-8. http://dx.doi.org/10.5897/ERR2013.1670

Ajayi, M. A., \& Fatokun, A. L. A. (2008). Effect of a six week emotional intelligence program on the sports performance of amateur athletes in oyo state of Nigeria. Sport Research Intelligence sportive.

Aslan, S., \& Özata, M. (2008). Duygusal zekâ ve tükenmişlik arasındaki ilişkilerin araştırılması: Sağlık çalışanları örneği. Erciyes Üniversitesi Iktisadi ve Idari Bilimler Fakültesi Dergisi, 30, 77-97.

Aslan, Ş., Akarçay, D., \& Ağcakaya, S. (2012). The mediator role of emotional intelligence which is effected by transformational and strategic leadership on ethical climate. Journal of Global Strategic Management, 11, 121-131. http://dx.doi.org/10.20460/JGSM.2012615792

Balçikanli-Sezen, G. (2010). Çok Boyutlu Sportmenlik yönelimi Ölçeği’nin Türkçe uyarlaması: geçerlik ve güvenirlik çalışması. Gazi Beden Eğitimi ve Spor Bilimleri Dergisi, 15(1), 1-10.

Balçikanli-Sezen, G. (2010). Çok Boyutlu Sportmenlik Yönelimi Ölçeği’nin Türkçe Uyarlaması: Geçerlik ve Güvenirlik Çalışması. Gazi Beden Ĕ̌itimi ve Spor Bilimleri Dergisi, 15(1), 1-10.

Balçıkanlı-Sezen, G., \& Yıldıran, İ. (2012). Sportspersonship Orientation and Empathy: A Study of Professional Football Players. Journal of Physical Education and Sport, 12(1), 18-24.

Bar-On, R. (2005). The Bar-On model of emotional-social intelligence. In P. Fernández-Berrocal and N Extremera (Guest Editors), Special Issue on Emotional Intelligence. Psicothema, 17.

Carmeli, A. (2003). The Relationship between emotional intelligence and work attitudes, behavior and outcomes. Journal of Managerial Psychology, 18, 788-813. http://dx.doi.org/10.1108/02683940310511881

Chan, D. W. (2004). Perceived emotional intelligence and self-efficacy among Chinese secondary school teachers in Hong Kong. Personality and Individual Differences, 36(8), 1781-1795. http://dx.doi.org/10.1016/j.paid.2003.07.007

Chan, D. W. (2006). Emotional intelligence and components of burnout among Chinese secondary school teachers in Hong Kong. Teaching and Teacher Education, 22(8), 1042-1054. http://dx.doi.org/10.1016/j.tate.2006.04.005

Çolakoğlu, T., Çolakoğlu, F., Adiloğulları, İ., Şenel, E., \& Yazgan, S. A. (2014). Examining general-self efficacy beliefs, self-confidence and emotional intelligence levels of elite athletes doing racket sports. (Mortan, K., Hristov, İ., Strelova, O., Kostova, Z. [Chief Eds.], Atasoy E., [Managing Ed.]), The Science and Education at the Beginning of the 21 St Century in Turkey, pp. 511-523, St. Kliment Ohridski University Press: Sofia.

Deshpande, S. P., \& Joseph, J. (2009). Impact of emotional intelligence, ethical climate, and behavior of peers on ethical behavior of nurses. Journal of Business Ethics, 85, 403-410. http://dx.doi.org/10.1007/s10551-008-9779-z

Duda, J. L., Olson, L. K., \& Templin, T. J. (1991). The relationship of task and ego orientation to sportsmanship attitudes and the perceived legitimacy of injurious acts. Research Quarterly for Exercise and Sport, 62, 79-87. http://dx.doi.org/10.1080/02701367.1991.10607522

Erdemli, A. (2008). Spor Yapan İnsan. E Yayınları, İstanbul.

Esturgo-Deu, M. E., \& Sala-Roca, J. (2010). Disruptive behaviour of students in primary education and emotional intelligence, Teaching and Teacher Education, 26(4), 830-837.

Goleman, D. P. (1995). Emotional Intelligence: Why It Can Matter More Than IQ for Character, Health and Lifelong 
Achievement. Bantam Books, New York.

Gürol, A., Özercan, M. G., \& Yalçın, H. (2010). A comparative analysis of pre-service teachers' perceptions of self-efficacy and emotional intelligence. Procedia Social and Behavioral Sciences, 2, 46-32. http://dx.doi.org/10.1016/j.sbspro.2010.03.496

Harrod, N. S., \& Scheer, S. D. (2005). An exploration of adolescent emotional intelligence in relation to demographic characteristics. From http://www.findarticles.com/p/articles/mi-m2248/is_159_40/ai_nl59 50403/pg_9 (November , 2014).

Hopkins, M. M., \& Bilimoria, D. (2008). Social and emotional competencies predicting success for male and female executives. Journal of Management Development, 27(1), 13-35. http://dx.doi.org/10.1108/02621710810840749

Humphrey, N., Curran, A., Morris, E., Farrell, P., \& Woods, K. (2007). Emotional intelligence and education: A critical review, Educational Psychology: An International Journal of Experimental Educational Psychology, 27(2), 235-254.

Isberg, L. (2000). Anger aggressive behavior, and athletic performance. Hanin, I.L. (Ed.), Emotions in sport. pp. 340-367, Human kinetics.

Kavussanu, M., \& Roberts, G. C. (2001). Moral functioning in sport: An achievement goal perspective. Journal of Sport and Exercise Psychology, 23(1), 37-54.

Lane, A. M., Devonport, T. J., Soos, I., Karsai, I., Leibinger, E., \& Hamar, P. (2010). Emotional intelligence and emotions associated with optimal and dysfunctional athletic performance. Journal of Sports Science and Medicine, 9, 388-392.

MacCann, C., Fogarty, G. J., Zeidner, M., \& Roberts, R. D. (2011). Coping mediates the relationship between emotional intelligence (EI) and academic achievement, Contemporary Educational Psychology, 36, 60-70.

Mayer, J. D., \& Salovey, P. (1997).What is emotional intelligence? (P. Salovey and D. J. Sluyter, Eds.) Emotional Development and Emotional Intelligence. New York: Basic Books.

McPail, K. (2004). An emotional response to the state of accounting education: Developing accounting students' emotional intelligence. Critical Perspectives on Accounting, 15(4-5), 629-648. http://dx.doi.org/10.1016/S1045-2354(03)00050-9

Parker, J. D. A., Creque, R. E, Barnhart, D. L., Harris, J. I., Majeski, S. A., Wood, L. M., Bond, B. J., \& Hogan, M. J. (2004). Academic achievement in high school: Does emotional intelligence matter? Personality and Individual Differences, 37, 1321-1330.

Pathak, R., Jaiswal, G., \& Patwardhan, M. (2013). A study of the relationship between emotional intelligence and ethical orientation. Prestige International Journal of Management \& IT-Sanchayan, 2(2), 108-116.

Pizarro, D. A., \& Salovey, P. (2002). On being and becoming a good person: The role of emotional intelligence in moral development and behavior. (J. Aronson, Ed.), Improving academic achievement: Impact of psychological factors on education, pp. 247-266, San Diego: Academic Press.

Rastegar, M., \& Memarpour, S. (2009). The relationship between emotional intelligence and self-efficacy among Iranian EFL teachers. System, 37, 700-707. http://dx.doi.org/10.1016/j.system.2009.09.013

Saarni, C. (1999). The development of emotional competence. New York: The Guilford Press.

Schutte, N. S., Malouff, J. M., Hall, L. E., Haggerty, D. J., Cooper, J. T., Golden, C. J., \& Dornheim, L. (1998). Developmentand validation of a measure of emotional intelligence. Personality and Individual Differences, 25(2), 167-177. http://dx.doi.org/10.1016/S0191-8869(98)00001-4

Şenel, E. (2013). Evaluation of some factors affectingself-efficacy beliefs of students in physical educationand sport teaching department and students in the some other fields of teacher education departments. Master Thesis, Unpublished. Gazi University. Institute of Educational Sciences.

Şenel, E., Adiloğulları, İ., \& Ulucan, H. (2014). Examination of emotional intelligence level, teacher's self-efficacy beliefs and general self-efficacy beliefs of teachers. Nigde University Journal of Physical Education and Sport Sciences, 8(2), 225-232.

Tsai, E., \& Fung, L. (2005). Sportspersonship in youth basketball and volleyball players. The Online Journal of Sport Psychology, 7(2), 37-46.

Valdesolo, P., \& DeSteno, D. (2007). Moral hypocrisy: Social groups and the flexibility of virtue. Psychological Science, 18, 689-690. http://dx.doi.org/10.1111/j.1467-9280.2007.01961.x 
Vallarand, R. J., Briere, N. M., Blanchard, C., \& Provencher, P. (1997). Development and validation of the multidimensional sportspersonship orientation scale.Journal of Sport and Exercise Psychology, 19(1), 197-206.

Weinberg, R. S., \& Gould, D. (2003). Foundation of Sport and Exercise Psychology. Champaign: Human Kinetics.

Weiss, M. R., \& Bredemeirer, B. J. (1990). Moral development in sport. Exercise and Sport Science Reviews, 18, 331-378. http://dx.doi.org/10.1249/00003677-199001000-00015

Yıldıran, İ., \& Sezen, G. (2006). Beden eğitimi öğretmeni adaylarının sportmenlik ve profesyonellik arasında ikilem barındıran somut örnek olaylara yaklaşımlarının değerlendirilmesi. Gazi Beden Eğitimi ve Spor Bilimleri Dergisi, $11(3), 3-14$.

Yin, H., Lee, J. C. K., Zhang, Z., \& Jin, Y. (2013). Exploring the relationship among teachers' emotional intelligence, emotional labor strategies and teaching satisfaction. Teaching and Teacher Education, 35, 137-145. http://dx.doi.org/10.1016/j.tate.2013.06.006

Zizzi, S. J., Deaner, H. R., \& Hirschhorn, D. K. (2003). The relationship between emotional intelligence and performance among college baseball players. Journal of Applied Sport Psychology, 15(3), 262-269. http://dx.doi.org/10.1080/10413200305390

This work is licensed under a Creative Commons Attribution 3.0 License. 